\section{CULTURE OF INTERETHNIC RELATIONS AS A CONDITION OF FORMATION OF YOUTH TOLERANT CONSCIOUSNESS}

\section{Problem definition}

Today it is obvious for everybody that interethnic communication is one of the most difficult or if it is the most difficult problem of social being, which we feel every day in different regions of the country. Specific, and sometimes unpredictable, contradictory actions of people are not recognized so acutely in any other field, as in this. Lack of knowledge about the other people, national stereotypes arouses psychological dissatisfaction among people which then transfer to the national stage.

The problems of interethnic relations have been arisen to the level of state interests and state policy. The message of President of Kazakhstan tells that civil world and intern-Ethnic concord are the main values and we are multi-ethnic society. Any double standards should not be [1]. That's why in contemporary social situation the actual is finding the tool of removal or reduction of inter-ethnic conflicts.

The problem of inter-ethnic communication has got key importance for poly-ethnic state. The low level of culture of mutual relations slows processes in multiethnic society and doesn't promote peaceful model of interethnic relations. Traditions of interaction between nations occupy an important place. Historical memory of Kazakhstan contains some experience of intercultural dialogue, tolerance and mutual respect.

The problem of tolerance is now becoming more urgent harmony of relationships, respect for individual peculiarities of other cultures, affiliations. It is a sign of confidence, reliability of their value priorities in life. Arising in different regions of republics and in the world the interethnic conflicts are due to insufficient training of people to independent social interaction, insufficient level of tolerance development.

It is necessary to promote respect to other nations and cultures among rising generation, readiness to cooperation and interaction, to decide human problems together it is necessary to teach how to respect every person, to teach a representative of other sociocultural group how to stimulate a desire to know another cultures, to teach how to head off and prevent conflicts. It is necessary to form knowledge, abilities and skills of tolerant behavior of a man who is 
opened for communication with other ethnic groups, people and nations.

\section{Analyses of the problem}

A number of socio-psychological theories used in the study of culture of interethnic relations. One of them is a theory of personality [2-7]. Among the researches who made a contribution in its development it should be named first of all such scientists as S.L. Rubinshtein, K.A. Abulkhanova-Slavskaya, A.V. Brushlinskiy, A. Lourens., P. Oliver., C.S. Hall, G. Lindsey [8-10].

Stressing the importance of thesis about interaction between culture and personality, it is necessary to separately underline the role of activity of the individual as self-regulating, self-governing system. Formed personality (internal) later will become the mediating link through which external influences on man (S.L. Rubinshtein).

Structural components of personality psychology are reproduced in group psychology. This is an interaction of motivating, cognitive and communicative processes. Social settings or attitudes are the result of psychological findings. Inter-ethnic relations are studying using these attitudes.

Personality is inextricably connected with activity [11-12]. The activity is always motivated that's why after the hierarchy of type of activity is the hierarchy of motives, and their respective needs. Active participation of personality in activity creates really opportunities for development of people with universal culture.

The instability of the society particularly affects young people. Youth due to age ability is characterized by perfectionism, the desire for a quick solution of social problems. Among adolescent growth of juvenile crime can be seen; the number of anti-social youth organizations, bearing extremist growing.

The school is one of the most important institutes of education of such character of ethnic aspect as tolerance. Tolerance is the sense of acceptance of another person, other views having the same right for existence.

Hence it can make a conclusion that the most effective method of forming tolerance is education which promotes for forming skills of critical thinking among children and to make judgments, independent thinking. Students learn how to practice tolerance. It means that they consider that people are differ by interests, positions, appearance and have the right to live in the world keeping their individuality.

At school a person is actively involved in adult life, forms his identity, and develops different social roles.
Global life orientation is depended on how a person will accept the world as a whole, to itself and the others in this world. Position of tolerance and confidence is the basis for implementation of the choice of the future generations in favor of peaceful coexistence of mankind. Rooting in the school spirit of tolerance, formation of attitude to it as to important value of society is a significant contribution of school education into the development of peace culture on Earth.

Modern science tells that today an objective reality makes to pay more attention to the development of culture of interethnic relations among schoolchildren. Therefore ethnic tolerance is necessary, i.e. the adoption of internal personal attitude with respect to values, cultural characteristics of other ethnic groups, readiness for interethnic contacts.

Ethnic tolerance is considered the dominant of culture of interethnic relations [11-12]. To develop it as a personal orientation (S.L. Rubinshtein, A.N. Leontiyev, V.N. Myasishev, B.G. Ananiyev) should be in the process of education, creating conditions for constructive interaction with representatives of other ethnic groups $[8,12]$.

Summarizing the various approaches to the concept of ethnic tolerance, we understand it as a complex socio - mental attitude of the person which is expressed in tolerance for other people's way of life, other customs, traditions, customs, different feelings, opinions and ideas.

We believe that tolerance is the cultural orientation, the attitude of the person who lives in peace and harmony in the country, family, school, class. Consequently, it implies the existence of such human qualities as responsibility, kindness, humility, tolerance. Unfortunately, the spirit of intolerance towards other cultures, lifestyles, beliefs, habits, continues to exist in society. School is not exception too.

Interethnic relations have always been studied with the aim of their harmonization, to prevent discrimination and regulation of stress and conflicts.

To study the culture of interethnic communication among teenagers we used the complex of the following methods:

1.Test "Are you a communicative man?" (V.F. Ryakhovskiy).

2.The method "The need for communication" (Yu.M. Orlov).

3.Test "Aggressiveness" (L.G. Pochebut).

4.Test "Cultural value orientations" (L.G. Pochebut).

The sample is the representatives of different ethnic groups of Kazakh, Russian and German nations took part at the age of 14-15 years old (30 children in each group). 
The results of researching the level of sociability among Kazakh teenagers showed that $50 \%$ of children are more communicative and another 50\% showed the norm of communication. The children were communicative, opened, and friendly. But at the same time they lack attentiveness and patience. They showed patience towards representatives of the other nationalities. They are not critical in their statements; they can listen to another point of view and adequately assess the situation.

The representatives of Russian group (58\%) are most communicative, curious, talkative, like statements on various issues, make acquaintances with pleasure, also want to be in the spotlight, nobody denied requests, although not always able to fulfill them, quite hot-tempered, they characterized by lack assiduity, patience when they are faced with serious problems, when they want, they can make themselves to hold ground.

The pupils of German experimental groups (48\%) showed themselves as communicative and tolerant in communication with children of the other nations. They have adequate self-esteem of their capabilities and purposes, prefer to communicate with people who are intellectually developed and interesting for them, but at the same time, they can be intolerant towards others.

One of the most important qualities of our psyche is need for communication with the similar. But the degree of need manifestation among different people is dissimilar. The higher the results obtained, the more a person seeks for others.

It was found that Kazakh teenagers (35\%) are characterized by the need for communication, they are communicative, curious, easily start a conversation with unknown people, they are always in the spotlight. They prefer noisy companies, as they usually have a lot of friends and acquaintances, but they have no one best friend, but it does not prevent them to have fun.

However, the most of them (55\%) is characterized by the average level of need for communication. It is said that children do not seek permanent location surrounded by other people, it is comfortable for him (her) to be alone, but it does not testify favorably that the children of this group are closed, but they are used to solve their problems and conflicts, by their nature, they are individualists.

Many of the children of German nationality (54\%) showed an average need for communication. It shows that that they contact with people with pleasure, they are not aggressive, characterized by cohesion and organization, showing interest only to that really interesting for them.
Unlike them the pupils of Russian group (58\%) showed the high level of need for communication, they contacts actively, try to be surrounded by friends, and prefer to work not alone but in group. But they heavily overcome the situations when the opportunities for communication are limited, it is very difficult for them to work alone, heavily depend on public opinion.

Next, we attempted to study aggression in communication. The study revealed its average level among Kazakh-teenagers (45\%). In communication with people of other nationalities, they do not seek to clarify the relationship with the help of physical aggression, and sort out their relationship with the help of words.

Teenagers of Russian nationality (48\%) showed an average level of aggressiveness. They are sociable and are not hostile toward others, it is easy to get contact with others for them and find a common language with almost all. They prefer to resolve all conflicts with words. And after a quarrel with someone they try to piece up a quarrel.

In the group of German teenagers significant differences in the degree of aggressiveness and adaptability were not found. They are distinguished by the average $(45 \%)$ and a low level (40\%) of aggression in communicating with others. They are also differed by certain degree of patience and tolerance.

Interpersonal relationships of adolescent with peers, arising accidentally or organized by adults, have got clear-cut individual, social-psychological characteristics. The stage of individualization is characterized by improvement and development of presentation about itself and formation the image of "I". Comparing with primary school consciousness among teenagers is intensively developed, expand selective contacts with peers.

Next we attempted to study cultural-value orientations of differentnationalities'representatives. The results of examination showed that the children of Kazakh group are orientated to traditional culture i.e. to the past, interest in history that explains their commitment to the traditions of their nation (66\%).

German teenagers are focused on contemporary culture $(70 \%)$ that explains their focus on the present, on contemporary events, which are clearly defined by status and role of the child in society.

Russian students $(68 \%)$ have proven to be harmoniously developing nation that keeps pace with the times. This is a dynamically developing culture, children focuses on the future, to achieve rapid and meaningful goals.

In addition, we have developed a program of correction behavior among adolescents. The teenage 
period is the most favorable for the development of communication skills and formation of them to a higher level of interethnic interaction. A sense of cultural identity of a person begins to take shape at this age, interest in matters cultural background increases.

The main facilities of organization of educational process that capable to form the culture of interethnic relations are: understanding of values of different cultures and personalities, dialog communication, situations of development and role games.

The culture of interethnic communication must be considered as integrative characteristics. It is necessary to make special psychological-pedagogic conditions to ensure the effectiveness of interethnic tolerance's formation among teenagers. To improve the culture of interethnic communication it is necessary to carry out special organized educational work.

\section{Conclusions}

The important place in society is belonged to the questions of interactions, comparison of different cultures, education systems in them. Everyone is under the influence of culture in which he grew up. But he has his own culture as a result of his upbringing. It can be the basis of arising trans-cultural problems in his interactions with other people.

In modern society the targeted educational strategy for formation positive tolerant relations in society is necessary. The meaning of tolerance is in active moral position and psychological readiness to patience for positive interaction with people of other culture, nation, religion, social environment

President of the Republic, in his message to the people of Kazakhstan emphasized: "In order to pass a global test for maturity, we must be united. We must strengthen the trust between all the citizens of Kazakhstan! Be tolerant to each other! These are the keys to the future of Kazakhstan. Interethnic harmony - is life-giving oxygen ... Our young people grow in the new, independent country" $[13 ; 14]$.

\section{References}

1 Poslanie Prezidenta Respubliki Kazahstan - lidera nacii N.A. Nazarbaeva narodu Kazahstana. Strategija «Kazahstan 2050»: Novyj politicheskij kurs sostojavshegosja gosudarstva // Kazahstanskaja pravda. - 15.12.2012 g.

2 Anan'ev B.G. Izbrannye trudy po psihologii: V 2-h tomah. Tom 1. - Izd-vo Sankt-Peterburgskogo universiteta, 2007. - 964 s.

3 Atkinson R.L., Atkinson R.S., Smit Je.E., Bem D.Dzh., Nolen-Hojeksema S. Vvedenie v psihologiju / pod obshhej red. V.P. Zinchenko. - 15-e mezhd. izd. - SPb.: Prajm-Evroznak, 2007.

4 Rubinshtejn S.L. Osnovy obshhej psihologii. - SPb.: Piter, 2009. - 713 s.

5 H'ell L., Zigler D. Teorii lichnosti. - 3-izd. - SPb.: Piter, 2008. - 609 s.

6 Lomov B.F. Sistemnost'v psihologii / In-t psihologii RAN, 2011. - $424 \mathrm{~s}$.

7 Gal'perin P.Ja. Lekcii po psihologii. - M.: Izdat. KDU, 2011. - 400 s.

8 Maslou A. Motivacija i lichnost'. - 3-e izd. - SPb.: Piter, 2016. - 352 s. (Mastera psihologii).

9 Lourens A., Oliver P. Psihologija lichnosti. Teorija issledovanija. - M., 2001. -607s.

$10 \mathrm{http}: / /$ cyberleninka.ru/article/n/kulturamezhnatsionalnogo-obscheniya-bazovyy-indikator-mezhnatsionalnyhotnosheniy\#ixzz3 RAV Onuqd.

11 Bondyreva S.K., Kolesov D.V. Tolerantnost'. Vvedenie v problemu. - SPb.: MPSI, MODJeK, 2011. - $240 \mathrm{~s}$.

12 Bakulina C D. Tolerantnost'. Ot istorii ponjatija k sovremennym sociokul'turnym smyslam: uchebnoe posobie. - SPb.: Flinta-Nauka, 2014. - $112 \mathrm{~s}$

13 Nazarbaev N.A. Plan nacii «100 konkretnyh shagov po realizacii pjati institucional’nyh reform». 2015.

14 Poslanie Prezidenta Respubliki Kazahstan narodu Kazahstana. - 11.11.2014.

\section{Литература}

1 Послание Президента Республики Казахстан - лидера нации Н.А. Назарбаева народу Казахстана. Стратегия «Казахстан - 2050»: Новый политический курс состоявшегося государства // Казахстанская правда. - 15.12.2012 г.

2 Ананьев Б.Г. Избранные труды по психологии: В 2-х томах. Том 1. - Изд-во Санкт-Петербургского университета, 2007. $-964 \mathrm{c}$.

3 Аткинсон Р.Л., Аткинсон Р.С., Смит Э.Е., Бем Д.Дж., Нолен-Хоэксема С. Введение в психологию / под общей ред. В.П. Зинченко. - 15-е межд. изд. - СПб.: Прайм-Еврознак, 2007.

4 Рубинштейн С.Л. Основы общей психологии. - СПб.: Питер, 2009. - 713 с.

5 Хьелл Л., Зиглер Д. Теории личности. - 3-изд. - СПб.: Питер, 2008. - 609 с.

6 Ломов Б.Ф. Системность в психологии / Ин-т психологии РАН, 2011. - 424 с.

7 Гальперин П.Я. Лекции по психологии. - М.: Издат. КДУ, 2011. - 400 с. 
8 Маслоу А. Мотивация и личность. - 3-е изд. - СПб.: Питер, 2016. - 352 с. (Мастера психологии).

9 Лоуренс А., Оливер П. Психология личности. Теория исследования. - М., 2001. - 607c.

$10 \mathrm{http} / /$ cyberleninka.ru/article/n/kulturamezhnatsionalnogo-obscheniya-bazovyy-indikator-mezhnatsionalny hotnosheniy\#ixzz3 RAV Onuqd.

11 Бондырева С.К., Колесов Д.В. Толерантность. Введение в проблему. - СПб.: МПСИ, МОДЭК, 2011. - 240 с.

12 Бакулина С.Д. Толерантность. От истории понятия к современным социокультурным смыслам: учебное пособие. СПб.: Флинта-Наука, 2014. - 112 с.

13 Назарбаев Н.А. План нации «100 конкретных шагов по реализации пяти институциональных реформ». 2015.

14 Послание Президента Республики Казахстан народу Казахстана. - 11.11.2014. 